\title{
Communication/Comunicação
}

\section{Natural infection of triatomines (Hemiptera: Reduviidae) by trypanosomatids in two different environments in the municipality of Ouro Preto do Oeste, State of Rondônia, Brazil}

\author{
Infecção natural de triatomíneos (Hemiptera: Reduviidae) por tripanosomatídeos em dois \\ ambientes distintos no município de Ouro Preto do Oeste, Estado de Rondônia, Brasil
}

\section{Dionatas Ulisses de Oliveira Meneguetti ${ }^{1}$, Olzeno Trevisan², Luís Marcelo Aranha Camargo ${ }^{3,4}$ and Renato Moreira Rosa ${ }^{5}$}

\section{ABSTRACT}

Introduction: This study analyzed the occurrence and the contamination of triatomines by trypanosomatids in Orbignya speciosa (babassu) specimens in the State of Rondônia, Brazil, in two different environments (pasture and woods). Methods: Capture of triatomines on babassus and microscopic search for trypanosomatids in their digestive tube were carried out. Results: Four hundred ninety-four (494) specimens were captured (Rhodnius prolixus and R.robustus), of which $35.6 \%$ of the triatomines were positive for trypanosomatids. Conclusions: The high index of natural infection along with the abundance of triatomines points out to the necessity to create an epidemiological surveillance system to monitor vector-borne transmission and deepen the studies on the ecology of such vectors in the Amazon.

Keywords: Triatomines. Chagas'disease. Amazon.

\section{RESUMO}

Introdução: $\mathrm{O}$ estudo analisou a ocorrência e o índice de contaminação por tripanosomatídeos de triatomíneos em Orbynia speciosa no Estado de Rondônia, Brasil, em 2 ambientes (pastagem e floresta). Métodos: Captura em palmeiras e esfregaços do conteúdo do tubo digestivo dos triatomíneos analisados por microscopia óptica. Resultados: Capturaramse 494 espécimes (Rhodnius prolixus e $R$. robustus), sendo que 35,6\% dos triatomíneos estavam positivos para tripanosomatídeos. Conclusões: O elevado índice de infecção natural, aliados à abundância de triatomíneos, mostram a necessidade de se criar um sistema de vigilância epidemiológica para monitorar a transmissão vetorial e aprofundar estudos sobre a ecologia destes vetores na Amazônia.

Palavras-chaves: Triatomíneos. Doença de Chagas. Amazônia.

Triatomines, also known as conenose bugs, kissing bugs, or assassin bugs, are insects largely spread throughout the Americas and are found from the South of the United States through the South of Argentina. They are of great importance, as they may convey the South American Trypanosomiasis, also called Chagas' disease ${ }^{1}$.

1. Departamento de Saúde, Faculdade de Educação e Meio Ambiente, Ariquemes, RO. 2. Departamento de Entomologia, Estação Experimental, Comissão Executiva do Plano da Lavoura Cacaueira, Ouro Preto do Oeste, RO. 3. Instituto de Ciências Biomédicas V, Universidade de São Paulo, Monte Negro, RO. 4. Departamento de Medicina, Faculdade São Lucas, Porto Velho, RO. 5. Departamento de Genética e Toxicologia, Universidade Luterana do Brasil, Canoas, RS.

Address to: Dr. Dionatas Ulisses de Oliveira Meneguetti. Dept ${ }^{\circ}$ Saúde/FAEMA. Av. Machadinho 4349, Setor 06, 76873-630 Ariquemes, RO, Brasil. Phone: $55693536-6600$

e-mail: dionatasmeneguetti@hotmail.com

Received in 02/02/2010

Accepted in 15/03/2011
In the State of Rondonia, the occurrence of seven species of triatomines has been reported in four genera, namely: Rhodnius robustus, Rhodnius prolixus, Rhodnius pictipes, Rhodnius milesi, Panstrongylus geniculatus, Eratyrus mucronatus, and Triatoma rubrovaria. However, T. rubroviaria is probably a taxonomic mistake ${ }^{2}$.

Many studies have pointed out the importance of babassus as a natural biotope, as they shelter a diversity of mammalian fauna such as bats, rats, opossums, and monkeys, besides snakes, birds, scorpions, amphibians, and a great variety of arthropods ${ }^{3}$. Such environment embodies a combination of shelter and food resources for the growth and procreation of triatomines, specially the species of the genus Rhodnius ${ }^{3}$, whose distribution on the sylvatic environment is strongly related to the distribution of palm trees ${ }^{4}$. On the other hand, the species of the Triatoma and Panstrongylus genus live rather in association with terrestrial hosts ${ }^{5}$. Over their evolutionary processes, only few species have adapted themselves to households and peridomiciliar animals ${ }^{6}$.

This study aimed to analyze the occurrence and the contamination of triatomines found in palm trees, such as Orbignya speciosa (babassu), by trypanosomatids in two different environments (primary forest and pasture) in the State of Rondônia, Brazil.

The study was carried out in the municipality of Ouro Preto do Oeste (S1044'53," W62 12'57”), located in the State of Rondônia, whose population is estimated to be at 36,725 inhabitants settled in a 1,970-km² area (population density of 18.6 inhabitant $/ \mathrm{km}^{2}$ ), located at $325 \mathrm{~km}$ from the state capital, the City of Porto Velho (Figure 1).

The research was carried out in two different environments one in a primary forest and the other in a pasture area. The collection of insects was done twice a month one in each environment within the period from February 2009 to January 2010, totaling 24 collections.

The collections done in a primary forest were carried out in the reserve of Comissão Executiva do Plano da Lavoura Cacaueira (CEPLAC) (S10 $42^{\prime} 49^{\prime}$, W62 $\left.{ }^{\circ} 13^{\prime} 31^{\prime \prime}\right)$, while the ones carried out in pasture areas were done in 12 farms: $\mathrm{C} 1-\left(\mathrm{S} 10^{\circ} 43^{\prime} 43, "\right.$ W62 $\left.{ }^{\circ} 14^{\prime} 29^{\prime \prime}\right)$; C2 - (S1044'10," W62 $\left.16^{\circ} 00^{\prime \prime}\right)$; C3 - (S10 43'26," $\left.\mathrm{W} 62^{\circ} 16^{\prime} 51^{\prime \prime}\right) ; \mathrm{C} 4-\left(\mathrm{S} 10^{\circ} 42^{\prime} 21\right.$, "W62 $\left.^{\circ} 17^{\prime} 90^{\prime \prime}\right)$; C5 - (S10 41'43," W62 $\left.{ }^{\circ} 6^{\prime} 29^{\prime \prime}\right)$; C6 - (S1041'16," W62 13'34"); C7 - (S10 44'16," $\left.\mathrm{W} 62^{\circ} 12^{\prime} 37^{\prime \prime}\right)$; C8 - (S1045'33," W62 13'32"); C9 - (S62 11'12," W62 $\left.{ }^{\circ} 11^{\prime} 12^{\prime \prime}\right) ; \mathrm{C} 10$ - (S62 $12^{\prime} 28$, , W62 $\left.^{\circ} 12^{\prime} 28^{\prime \prime}\right) ; \mathrm{C} 11$ - (S10 39'38," W62 $\left.{ }^{\circ} 15^{\prime} 34^{\prime \prime}\right)$; and $\mathrm{C} 12-\left(\mathrm{S} 10^{\circ} 45^{\prime} 26\right.$, $\left.^{\prime \prime} \mathrm{W} 62^{\circ} 90^{\prime} 58^{\prime \prime}\right)$, all of them located in the vicinities of the municipality of Ouro Preto do Oeste. 


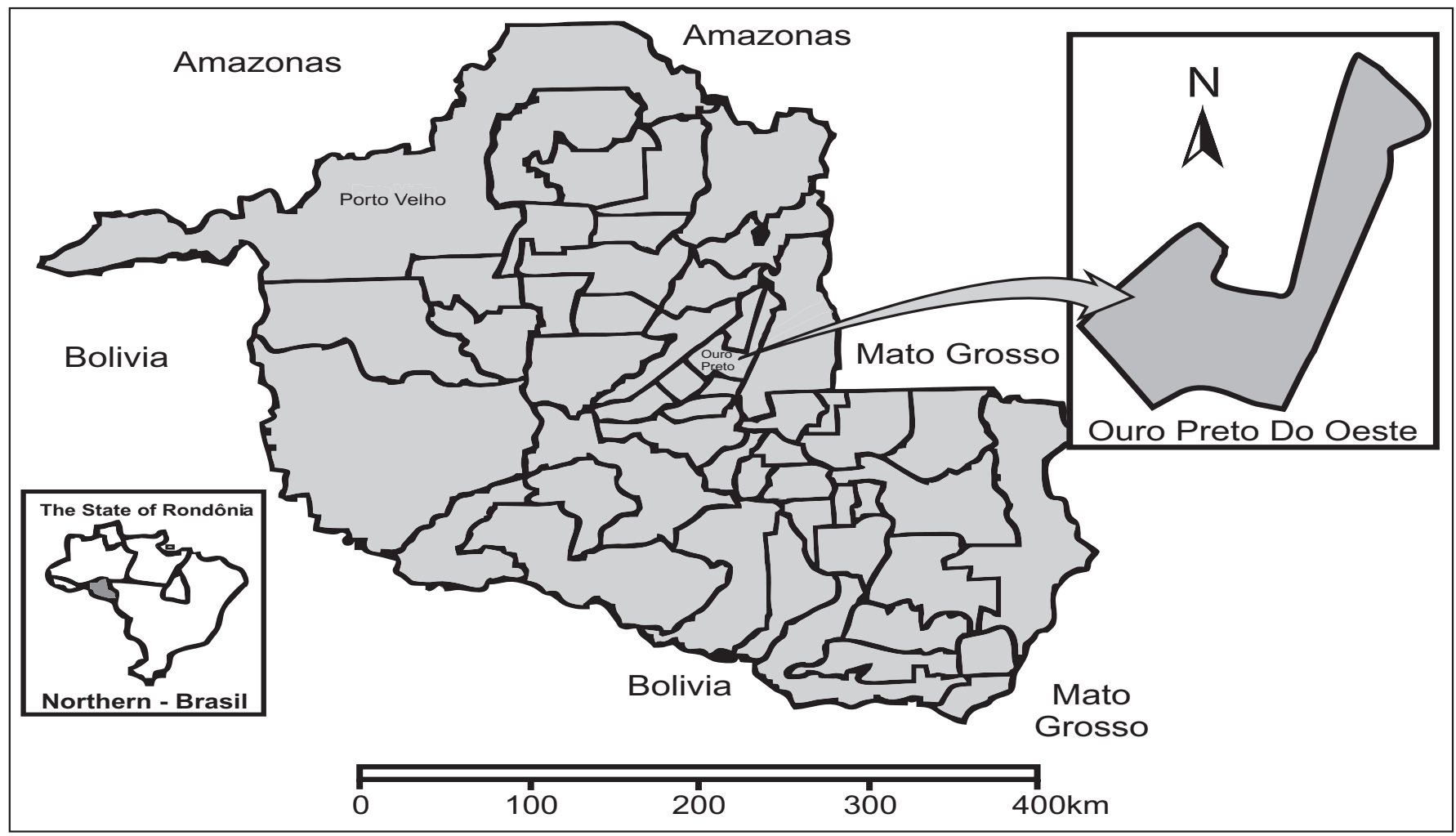

FIGURE 1 - Geographical location of the municipality of Ouro Preto do Oeste, State of Rondônia, Brazil.

In each collection, one babassu was examined (Instituto Brasileiro do Meio Ambiente e dos Recursos Naturais Renováveis (IBAMA) permanent license nr. 14934-1). These trees were randomly picked out after sorting 20 palm trees in each area.

The babassus were cut off with a chain saw. Then, the bracts (where a large quantity of invertebrates and small vertebrates can inhabit) were taken off one-by-one in order to facilitate the capture of triatomines (Figure 2).

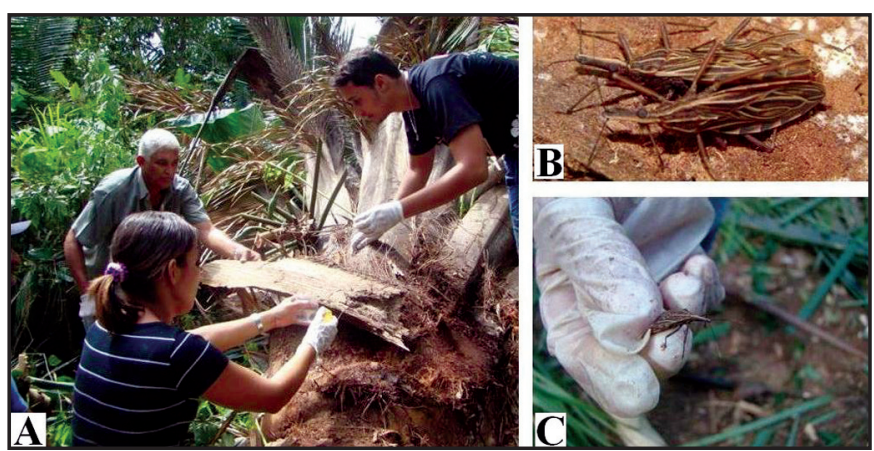

FIGURE 2 - Active search for triatomines on Orbignya speciosa (babassu).

A: Cutting off the bracts; B: Triatomine mating during the collection procedure; C: A triatomine being picked up.

The triatomines picked-up were sorted according to their nymphal stage and were then sent to the Centro Universitário Luterano de Ji-Paraná/Universidade Luterana do Brasil (CEULJI/ ULBRA) - The Microscopy Laboratory of the Lutheran University

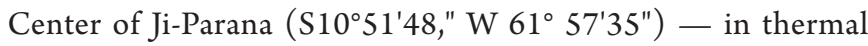
boxes at room temperature where the digestive tube content was diluted in saline solution, prepared on microscope slides, and then examined with a microscope using a $16 \mathrm{x}$ and $40 \mathrm{x}$ objective lenses. The microscopic examination was rigorous, covered the whole slide, and was considered positive when flagellated protozoa were found.
Then, the smears were soaked in methanol, stained with Giemsa, and again observed by optical microscopy to confirm their positivity for the presence of trypanosomatids.

After the analysis, the triatomines were sent to the CEPLAC in the estação expermental (ESTEX) — Laboratory of Entomology of Ouro Preto do Oeste of the Rondônia (S1043'33,"W62 $\left.14^{\prime} 20^{\prime \prime}\right)$ for taxonomic identification according to their external morphological characteristics, by using the dichotomous key of Lent \& Wygodzinsky, $1979^{7}$.

In the 24 examined babasuss, a total of 494 triatomines were found -78 in the 12 babasuss of the primary forest and 416 in the other 12 babassus of the pasture area. In both environments, $100 \%$ of the babassus picked-out were found to be positive for triatomines (Figure 3).

Overall, a density of 20.6 triatomines was found for each babassu - being 34.7 in the pasture area and 6.5 in the primary forest (Hartley's f test $=471.55, \mathrm{p}<0.0000001)$.

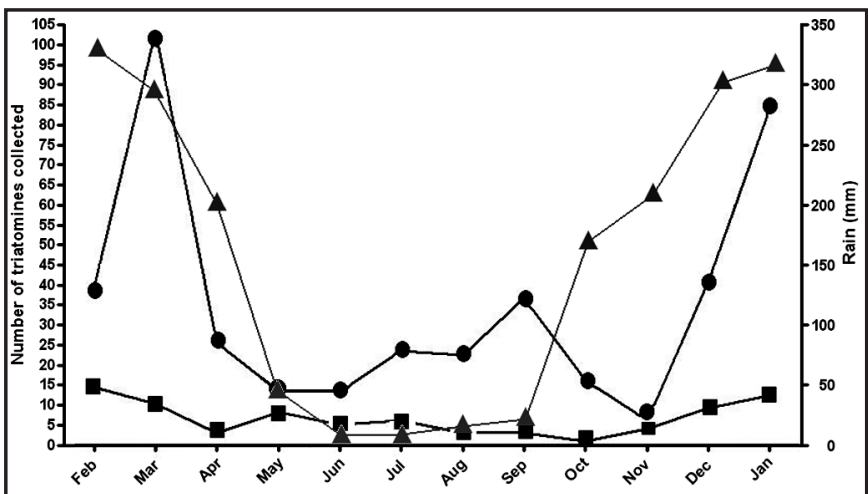

FIGURE 3 - Triatomines captured on Orbignya speciosas (babassu) located in a primary forest and pasture area, from February 2009 to January 2010, and the pluvial monthly average precipitation in the municipality of Ouro Preto do Oeste, State of Rondônia, Brazil.

-: pasture area, $\bullet$ : primary forest, $\boldsymbol{\Delta}$ : rain $(\mathrm{mm})$. 
In both environments, the period with greater triatomine capture index was from October to March (55.7 triatomines per month), the rainy season, when compared with the period from April to September (22.0 triatomines per month), the dry season (Hartley's $\mathrm{f}$ test $=22.0681, \mathrm{p}<0.0000001)$. The triatomines collected belong to the genus Rhodnius and are sorted into two species: Rhodnius robustus 459 (92.9\%) and Rhodnius prolixus 35 (7.1\%), with 390 (93.8\%) R. robustus and $26(6.2 \%)$ R. prolixus in the pasture area and 69 (88.5\%) R. robustus and $9(11.5 \%)$ R. prolixus in the primary forest, respectively.

The triatomines collected were sorted according to their stages and were analyzed for their positivity for trypanosomatids.

Out of the 494 specimens analyzed, 176 (35.6\%) were found to be positive for trypanosomatids (not necessarily Trypansosoma cruzi). In the primary forest, the index, although higher $(42.6 \%)$ when compared with the pasture area $(34.1 \%)$, showed no statistical difference $\left(\mathrm{X}^{2}=2.560\right.$ and $\left.\mathrm{p}=0.1096\right)$, demonstrating no environmental influence on the results.

The numbers of captured triatomines contaminated by trypanosomatids morphologically resembling T. cruzi were: nymph-1 - 18 (0\%); nymph-2 - 69 (2\%); nymph-3 - 134 (19\%); nymph-4 - 103 (44\%); nymph-5 - 64 (40\%); and adults $-106(71.7 \%)\left(X^{2}=122.066\right.$ and $p \leq 0.0001,5$ d.1. $)$, suggesting that the higher the developmental stage of the triatomines, the higher the percentage of infection. In both environments, the highest contamination index was found in the adult stage: $72.2 \%$ in the primary forest and $71.6 \%$ in the pasture area.

The high (100\%) frequency of positive babassus for the presence of triatomines and the high density of 20.6 individuals for each palm tree are above the frequency found in other similar studies: In the City of Uberlandia, State of Minas Gerais (Southwest), the findings were $93.7 \%$ of the palm trees, with a density of 15.5 specimens ${ }^{8}$. In the City of Monte Negro (North), Rondônia, the frequency was $85 \%$, with a density of 2.9 specimens ${ }^{9}$. In the federal district, the frequency varied between $1 \%$ and $40 \%$ and had an average of 3.3 to 9.0 specimens for each palm tree ${ }^{10}$.

The highest occurrence of triatomines took place in the pasture area with 416 bugs captured and an average of 34.7 specimens for each babassu, which is different from the number found in the primary forest in which the average was 6.5. Such smaller occurrence of triatomines in the primary forest is probably due to a greater biodiversity of trees, especially other palm trees (Euterpeoleracea, Iriartea spp., Oenocarpus bacaba, and Mauritia flexuosa). Therefore, the vectors have more sheltering options and more food availability on several trees, which did not occur in the pasture area where the sheltering options and food availability are provided only by the babassu perfectly adapted to the pasture area. Due to the scarcity of options in this area, they are concentrated in the existing babassus.

The months of October and March, the period in which a greater quantity of triatomines were captured, are in conformity with the highest indexes of pluvial precipitation that occur in the municipality of Ouro Preto do Oeste, Rondônia. This is similar to other studies in which the highest capture index took place during the rainy periods ${ }^{3}$. Some studies on the dynamics of the triatomine populations indicate that its dispersion to form new colonies takes place in the rainy periods in a tropical environment ${ }^{10}$.

The prevalence of the Rhodnius genus on palm trees is reported in other studies carried out in deforested areas of the municipality of Manaus, state of Amazonas ${ }^{11}$, and Monte Negro, State of Rondônia9.
The species $R$. robustus, that had a higher incidence, has already been found in the peridomestic habitats and habitats infected by T. cruzi, which is considered a potential vector for the transmission of Chagas' disease ${ }^{12}$. Its occurrence is described in the States of Maranhão, Goiás, Amazonas, Pará, ${ }^{73}$, and Rondônia ${ }^{2,9}$.

Rhodnius prolixus has been reported as having domiciliary transmission, and its domiciliation is taken as a consequence of deforestation, which makes it an important vector for the occurrence of Chagas' disease in Central America ${ }^{14}$. Its occurrence is described in the States of Maranhão, Goiás, Pará, Rio de Janeiro ${ }^{7,10,13}$, Minas Gerais, São Paulo, Pernanbuco, Piauí ${ }^{11}$, and Rondônia ${ }^{2,9}$.

The two species are distinguished by the following characteristics. $R$. robustus is considered larger species - length of males is 20-23.5 $\mathrm{mm}$ and of females is $23-26 \mathrm{~mm}$; the anteocular region is about four times as long as the postocular; and the distance between the eyes is dorsally smaller than or equal to the width of the eyes in dorsal view. $R$. prolixus is considered a smaller species — length of males is $17.5-20.0 \mathrm{~mm}$ and of females is $19.5-21.5 \mathrm{~mm}$; the anteocular region is slightly over three times as long as the postocular; and in most specimens, the distance between the eyes is dorsally larger than the width of the eyes in dorsal view ${ }^{7}$.

The total index of $35.6 \%$ of positivity for triatomines infected with trypanosomatids is higher than the $23.7 \%$ registered in a research carried out in Monte Negro, Rondônia ${ }^{9}$. Nevertheless, the previous study reports the contamination by $T$. cruzi detected by culture, and the present study reports contamination based on the observation of flagellated protozoa using the optical microscopy. It is not possible to determine the species principally because of the common occurrence of Trypanosoma rangeli in triatomines of the genus Rhodnius. With that, future studies to better characterize the species of trypanosomatids occurring in triatomines in the state of Rondônia are recommended.

The high contamination index in the adult stage is due to the fact that adults have eaten more often, therefore increasing the probability of catching the etiologic agent from the hosts, as in this stage, they have wings and can move from one tree to another or even to the houses, increasing the potential of these insects being vectors of Chagas' disease.

Such data is worrisome, as in the pasture areas, there are plenty of babassus near the houses, and they may allow these vectors to infest the habitats and, consequently, carry the etiologic agent, T. cruzi, that causes the American Trypanosomiasis.

High natural infection indexes along with the abundance of triatomines show the need to create an epidemiologic surveillance system to monitor the occurrence of cases of vector-borne transmission of Chagas' disease and carry out further studies on the ecology of these vectors in the Amazon.

\section{CONFLICT OF INTEREST}

The authors declare that there is no conflict of interest.

\section{REFERENCES}

1. Dias E, Dias JCP, Garcia ALR, Dias RB, Machado ENM, Gouveia SC, et al Doença de Chagas: Textos de apoio. Brasília: Ministério da Saúde. Superintendência de Campanhas de Saúde Pública; 1989. 
2. Meneguetti DUO, Trevisan O, Rosa RM, Camargo LMA. First report of Eratyrus mucronatus, Stal, 1859, (Hemiptera, Reduviidae, Triatominae) in the State of Rondônia, Brazil. Rev Soc Bra Med Trop 2011; 44:511-512.

3. Gonçalves RG, Duarte MA, Ramalho ED, Palma ART, Romana CA, Cuba CA. Distribuição espacial de populações de triatomínios (Hemiptera: Reduviidae) em palmeiras da espécie Mauritia flexuosa no Distrito Federal, Brasil. Rev Soc Bra Med Trop 2004; 37:241-247.

4. Gaunt MF, Miles MA. The ecotopes and evolution of triatomine bugs (Triatominae) and their associated trypanosomes. Mem Inst Oswaldo Cruz 2000; 95:557-565.

5. Ministério da Saúde. Atenção Básica. Vigilância em saúde: zoonoses. Brasília: Secretaria de Atenção à Saúde. Departamento de Atenção Básica; 2009.

6. Organização Pan-Americana de Saúde. Doença de Chagas: Guia para vigilância, prevenção, controle e manejo clínico da doença de chagas aguda transmitida por alimentos. Serie de Manuais Técnicos. Rio de Janeiro: PANAFTOSA-VP/OPAS/ OMS; 2009.

7. Lent H, Wygodzinsky P. Revision of the Triatominae (Hemiptera, Reduviidae), and their significance as vectors of Chagas' disease. Bull Am Mus Nat Hist 1979; 163:127-520.

8. Barretto MP, Albuquerque DRR, Funayama GK. Estudos sobre reservatórios e vectores silvestres do Trypanosoma cruzi. XXXVI: Investigação sobre triatomíneos de palmeiras no município de Uberaba, MG, Brasil. Rev Bras Bio $1969 ; 29: 577-588$

9. Massaro DC, Rezende DS, Camargo LMA. Estudo da fauna de triatomíneos e da Ocorrência de Doença de Chagas em Monte Negro, Rondônia, Brasil. Rev Bras Epidemiol 2008; 11:228-240.

10. Mendes PC, Carmo S, Beatriz LM, Paula C, Souza AA, Rodrigues EAS, et al. Doença de chagas e a distribuição espacial de triatomíneos capturados em Uberlândia, Minas Gerais - Brasil. Rev Bras Geo Med Saude 2008; 3:176-204.

11. Naiff MF, Naiff RD, Barrett TV. Vetores selváticos de doença de Chagas na área urbana de Manaus (AM): atividade de vôo nas estações secas e chuvosas. Rev Soc Bras Med Trop 1998; 31:103-105.

12. Miles MA, Souza AD, Povoa M. Chagas disease in the Amazonia basin. Ecotopes of tem triatomine bug species (Hemiptera, Reduviidae)from the vicinity of Belém, Pará state, Brazil. J Med Entomol 1991; 18:266-278.

13. Carcavallo R, Gallindez Girón I, Jurberg J, Lent H. Atlas of Chagas' Disease Vectors in the Americas/ Atlas dos vetores da doença de Chagas nas Américas. Vol I. Rio de Janeiro: Editora FIOCRUZ; 1998.

14. Zeledón R. Some historical facts and recent issues related to the presence of Rhidnius prolixus (Stal,1859) (Hemiptera: Reduviidae) in central America. Entomol Vect 2004; 11:233-246.

\section{Erratum}

\section{Revista da Sociedade Brasileira de Medicina Tropical/Journal of the Brazilian Society of Tropical Medicine}

Title: Natural infection of triatomines (Hemiptera: Reduviidae) by trypanosomatids in two different environments in the municipality of Ouro Preto do Oeste, State of Rondônia, Brazil

Vol. 45(3): 2012 - Page: 395-398, - doi: 10.1590/S0037-86822012000300023

In regard to the triatomines collected in the present study, where we cite:

Rhodnius prolixus and R. prolixus.

\section{Should read:}

Rhodnius montenegrensis and R. montenegrensis. 